\title{
Consumers Lobby Against Monopolies v. Public Utilities Commission: The PUC's Power to Award Attorney Fees
}

Consumers Lobby Against Monopolies (CLAM) v. Public Utilities Commission (PUC) ${ }^{1}$ concerned a challenge to two PUC decisions ${ }^{2}$ in which the PUC had disclaimed any authority to award attorney fees. A divided California Supreme Court reversed one decision, holding that the PUC has equitable authority to award fees in reparations cases. ${ }^{3}$ The court affirmed the other decision, holding that the PUC inay not award fees to participants in ratemaking proceedings. ${ }^{4}$ The court reasoned that because reparations proceedings are "quasi-judicial" and closely reseinble court proceedings, judicially created attorney fee doctrines should apply to them. In contrast, the court found ratemaking proceedings to be "quasi-legislative" in character, making thein inappropriate contexts for attorney fee awards under the judicial doctrines. ${ }^{5}$

1. 25 Cal. 3d 891, 603 P.2d 41, 160 Cal. Rptr. 124 (1979) (Mosk, J.).

2. Decision No. 88533,83 Cal. PUC 484 (1978); Decision No. 88532, 83 Cal. PUC 471 (1978).

The PUC is a constitutionally established administrative agency. CAL. Const. art. 12, $\$$ 1-6. The legislature has "plenary power" to delegate authority to the PUC, id. \$ 5 , and has given it the power to "regulate every public utility in the State" and to "do all things . . . which are necessary and convenient" to such regulation. CAL. PuB. UTIL. Code $\$ 701$ (West 1975).

3. In a reparations proceeding, a complainant alleges that a utility has charged an "unreasonable, excessive, or discriminatory annount" in violation of the rates set by the PUC. If the Commission finds the complaint justified, it awards reparations, plus interest from the date of collection, to the utility customers who have been overcharged. CAL. PuB. UTIL. Code $\$ 734$ (West 1975).

4. In ratemaking proceedings the PUC fixes rates for utilities under its statutory mandate to "determine and fix, by order, the just, reasonable, or sufficient rates." CAL. PUB. UTIL. CoDE $\S 728$ (West 1975). In California Mfrs. Ass'n v. PUC, 24 Cal. 3d 251, 256-57, 595 P.2d 98, 100, 155 Cal. Rptr. 664, 666 (1979), the court described ratemaking as follows:

In a general rate setting proceeding, the commission determines for a test period the utility expense, the utility rate base, and the rate of return to be allowed. Using those figures, the commission determines the revenue requirement, and then fixes the rates for the consumers to produce sufficient incoine to ineet the revenue requirenient.

5. Only Justice Mosk beheved reparations proceedings should be treated differently fron ratemaking proceedings. Chief Justice Bird and Justices Tobriner and Newinan concurred in those parts of Justice Mosk's opinion that concluded the PUC may award attorney fees im reparations proceedings, but they considered attorney fee awards also appropriate in rateinaking cases. $25 \mathrm{Cal} .3 \mathrm{~d}$ at 918, 603 P.2d at 57, $160 \mathrm{Cal}$. Rptr. at 140 (Newman, J., concurring and dissentimg). In contrast, Justices Clark, Richardson, and Manuel agrced with Justice Mosk that the PUC lias no authority to award attorney fees in ratemaking, but believed that the PUC likewise has no 
Moreover, the court rejected the contention that the PUC has statutory authority to award attorney fees to ratemaking participants.

This Note argues that the court's "quasi-judicial" and "quasilegislative" labels are inadequate standards for determining when the PUC should award attorney fees. It proposes that the Commission determine whether an attorney fee award is appropriate by reference to the requirements and underlying policies of each of the judicially created attorney fee doctrines. This Note also argues that the court should permit the PUC to initiate a reimburseinent program for ratemaking participants if it chooses to do so.

Part I of this Note summarizes the facts and holding in CLAM. Part II describes the judicial doctrines authorizing awards of attorney fees and discusses the current legal status of fee awards by admmistrative agencies. Part III discusses the court's analysis, agreeing with the court that the PUC has equitable power to award attorney fees, but arguing that the court's distmction between quasi-judicial and quasilegislative proceedings does not encompass all of the concerns appropriate to a decision whether to award attorney fees. Part IV proposes an alternative analysis based on the pohicies underlymg the attorney fee doctrines. Fimally, Part V recommends that the court defer to the PUC should it decide to create an attorney fee reimbursement prograin for ratemaking participants.

I

The COURT'S OpINION

\section{A. Facts}

In CLAM the supreme court reviewed two separate, unrelated PUC proceedings: a reparations proceeding and a ratemaking proceeding. In the former, CLAM filed a complaint with the PUC alleging that Pacific Telephone shifted costs to general residential ratepayers that were properly chargeable to commercial ratepayers. The plaimtiff sought refunds froin Pacific Telephone on behalf of the residential ratepayers. CLAM's allegations were never tested in a formal PUC hearing, because Pacific Telephone agreed to a settlement, consenting to spend $\$ 400,000$ from its accumulated profits on a "public benefit" approved by the PUC. ${ }^{6}$ CLAM then petitioned the PUC for attorney fees and costs. The PUC denied the fee request, claiming it had no authority to make such an award. CLAM sought review in the Califorma

authority to grant fee awards in reparations cases. Id. at 916,603 P.2d at 56, $160 \mathrm{Cal}$. Rptr. at 139 (Richardson, J., concurring and dissenting).

6. As of April 13, 1981, the PUC still had not decided how to use the fund. Telephone interview with John Mallory, Assistant Chief Administrative Law Judge, Public Utilities Commission, San Francisco, California (April 13, 1981). 
Supreme Court, ${ }^{7}$ where both Pacific Telephone and the PUC opposed its fee request. ${ }^{8}$

The other PUC decision appealed in CLAM arose out of ratemaking proceedimgs concerning Pacific Telephone's general rate application for "single message rate timing" (SMRT). ${ }^{9}$ A consumer group, Toward Utility Rate Normalization (TURN), actively opposed SMRT. TURN claimed its participation in the ratemaking proceedings resulted in three benefits for the ratepayers. First, TURN was the only party to question the constitutionality of Pacific Teleplione's practice of momtoring solne customer telephone conversations. After TURN challenged the practice, the PUC acknowledged its constitutional infirmity and ordered Pacific Telephone to cease momitoring conversations without notice. ${ }^{10}$ Second, TURN was the only party to challenge the PUC's violation of its own procedural rules in connection with its modification of an earlier PUC decision. ${ }^{11}$ TURN claimed that this challenge resulted in the PUC admittmg illegality and voiding the unlawful modification. Third, TURN claimed that it significantly contributed to the PUC's decision to eliminate SMRT on lifeline service, resulting in lower rates and rebates to customers of charges collected subject to refund during the pendency of the hearing. ${ }^{12}$ TURN sought attorney fees and costs for its participation. The PUC demed that it was authorized to grant thein. TURN sought review in the California Supreme Court, where, as in the CLAM appeal, both Pacific Telephone and the PUC opposed awarding fees.

7. The only judicial review of PUC decisions is by the California Supreme Court. CAL. Pub. UtIL. CoDE $\S \S 1756,1759$ (West 1975).

8. A secondary issue in the case was whether the PUC could award fees to a nonattorney. CLAM had only one member, David Wilner. Wilner was not an attorney, but he was permitted to represent CLAM because the PUC does not require that those who appear before it in a representative capacity be attorneys. 20 CAL. ADMIN. CODE $\S 4$ (July 14, 1967). Due to this policy, the court held that the PUC could award CLAM attorney fees despite the fact that it was not represented by an attorney. The court reasoned that the PUC's practice of allowing nonattorneys to appear in a representatiave capacity indicated that the PUC regarded such persons as fully competent in PUC proceedings. The court also explained that denying CLAM an attorney fee award because Wilner was not an attorney would be imconsistent with the common fund attorney fee policy, because if CLAM did not receive a fee award, the beneficiaries of the fund would be unjustly enriched. $25 \mathrm{Cal} .3 \mathrm{~d}$ at $913-15,603$ P.2d at 54-55, $160 \mathrm{Cal}$. Rptr. at 137-38.

9. Single message rate timing is a usage-sensitive technique for billing. It times and charges local calls by periodic intervals. See Toward Utility Rate Normalization (TURN) v. PUC, 22 Cal. 3d 529, 534, 585 P.2d 491, 493, 149 Cal. Rptr. 692, 694 (1978).

10. See Decision No. 88232, 83 Cal. PUC 149 (1977); Decision No. 86594, 80 Cal. PUC 621 (1976); note 113 infra.

11. See Decision No. 87584, 82 Cal. PUC 162, 170 (1977). The Commission's violation was in modifying the effective date of the SMRT decision after it had already become effective contrary to the rule announced in Decision No. 70415, 65 Cal. PUC 280 (1966).

12. See Decision No. 87584, 82 Cal. PUC 162 (1977); Decision No. 86594, 30 Cal. PUC 621 (1976). 


\section{B. The Court's Analysis}

\section{The Decision in the Reparations Case}

The court reversed the PUC's decision in the reparations proceedings, holding that the PUC does have authority to grant attorney fees in such actions under the judicially created common fund doctrine. ${ }^{13} \mathrm{Al}-$ though no statute expressly grants the PUC discretion to award fees, the court concluded that the PUC's expansive authority under Public Utilities Code section 701 to "do all things . . . necessary and convenient" in regulating utilities ${ }^{14}$ made more explicit statutory authorization unnecessary. The court reasoned that in reparations proceedings the PUC, although it is not a constitutionally established judicial department, does have "well established" judicial powers, including equitable powers. ${ }^{15}$ The court noted that in deciding reparations cases the PUC had taken over a function that had previously been perforined by courts. ${ }^{16}$ Because a court would have had equitable authority to award fees in a reparations suit, the court decided that the PUC should also be permitted to award fees in such cases.

The court rejected the argument that charging ratepayers to pay the fees of consumer advocates is, in effect, niaking consumers pay twice for representation, as the PUC staff is already paid froin public funds. ${ }^{17}$ The court noted that the PUC is not always an adequate representative of the public: the PUC is subject to institutional pressures

13. Before reaching the merits of CLAM's attorney fees claim, the court dismissed the argument raised by the PUC and Pacific Telephone that the court had already established that the PUC could not award fees. This argument was based on the court's denial, in unpublished minute orders, of two petitions for writ of review of earlier PUC decisions which laad leeld that the PUC was without power to award fees. See Toward Utility Rate Normalization v. PUC, S.F. 23395 (Oct. 17, 1976); Citizens to Save Fallbrook's Environment v. PUC, S.F. 23067 (July 31, 1974). The PUC and Pacific Teleplone argued that these writ denials had stare decisis effect under People v. Western Airlines, Inc., 42 Cal. 2d 621, 630-31, 268 P.2d 723, 728 (1954), where the court said: "[D]emial by this court of a petition for review of an order of the [PUC] is a decision on the merits both as to the law and the facts . . . even though the order of this court is without opinion." The CLAM court disagreed, saying the Western Airlines language referred only to the res judicata effect that barred relitigation of the same issues by the same parties in the same case. 25 Cal. $3 \mathrm{~d}$ at 899-905, 603 P.2d at 45-49, 160 Cal. Rptr. at 128-32.

14. Cal. Pub. Util. Code $\$ 701$ (West 1975).

15. 25 Cal. 3d at 906,603 P.2d at 50, 160 Cal. Rptr. at 133 .

16. Prior to the establishment of the PUC, the courts were the only forum in which a claim for reparations could be adjudicated. See Southern Pac. Co. v. Railroad Comun'n, 194 Cal. 734, 737-38, 231 P. 28, 29-30 (1924).

17. Most of the PUC's budget, including provision for a large legal staff, comes from the state. See, e.g., 1979-80 Cal. Adv. Legis. Serv. cl. 510. If the PUC were to pay attonney fees to participants, the fees would probably be included as an operating expense of the utilities and passed on to the ratepayers. See text accompanying notes 164-165 infra. Pacific Teleplione and the PUC argued that passing fee costs on to the ratepayers would foree them to protect their interests twice: once as taxpayers, paying to finance the operations of the PUC; once as ratepayers, paying to finance the attorney fees of participants in PUC proceedings. $25 \mathrm{Cal} .3 \mathrm{~d}$ at 908,603 P.2d at 51, 160 Cal. Rptr. at 134. But see text accompanying notes 67-69 infra. 
that inay create conflicts of interest, and in fact, in the present case, the PUC had refused to investigate CLAM's initial charges. ${ }^{18}$

Finally, the court was not persuaded that allowing attorney fees in reparations cases would cause undue administrative problens for the PUC. It pointed out that the PUC could deal with any administrative problems that might result froin increased public participation ${ }^{19}$ by using its general ruleinaking powers. ${ }^{20}$ Moreover, the court implied that it would allow the PUC a wide latitude in deciding who qualified for a fee award, noting that the equitable doctrines were designed to permit fees "in only the most meritorious cases" and that, according to traditional equitable principles, attorney fee awards would lie in the sound discretion of the PUC, reviewable only for "clear abuse of . . . discretion." 21

Three justices disagreed with the majority's decision to permit attorney fees $\mathrm{m}$ reparations proceedings. ${ }^{22}$ In an opinion authored by Justice Richardson, these justices argued first that section 1021 of the California Code of Civil Procedure ${ }^{23}$ precludes all attorney feeswhether awarded by a court or by the PUC-in the absence of express statutory authorization. The majority rejected this argument, pointing to well-recognized equitable exceptions ${ }^{24}$ to section 1021 that permit

18. The court also pointed out that the PUC staff could not serve as an adequate public representative because it is limited by statute from seeking rehearing. CAL. PuB. UTIL. CodE $\S 1731$ (West Supp. 1981), or judicial review, $i d$. $\$ 1756$ (West 1975), of Commission decisions. More importantly, even without these statutory limits, the PUC staff members would be unlikely to seck rehearing or judicial review of the decisions of their employer-the PUC-even if the staff believed the decision erroneous from the consumers' viewpoimt.

19. While the court seemed concerned only with the administrative problems that might result from an increased volume of public participation, the PUC's authority to award fees to successful reparations clainiants could also raise other administrative problems. For example, when the PUC staff attorneys participate in a proceeding, the PUC will have to decide how much the public participant contributed in proportion to the contributions of its own staff. The CLAM reparations proceedings illustrate the problem. After CLAM had instituted the action by filing a formal reparations complamt, an admimistrative law judge imstructed the PUC staff to take over the mvestigation. See Brief of Consumers Lobby Against Monopolies at 8. CLAM argued that it was nevertheless entitled to fees for its contimued participation in the investigation. Id. The PUC should be able to deal with this problem under its rulemaking power. It has, for example, already formulated detailed rules to assess the value of public contributions in electric utility ratemaking ltearings under a federally designed reimbursement program. See notes $154 \& 162$ infra.

20. This rulemaking authority is delegated to the PUC by CAL. ConST. art. $12, \S 2$ ("the commission may estabhslı its own procedures") and by CAL. PUB. UTIL. CoDE $§ 1701$ (West 1975) ("All hearings, investigations, and proceedings shall be governed by this part and by rules of practice and procedure adopted by the commission . . . .").

21. 25 Cal. $3 d$ at 908,603 P.2d at 51, 160 Cal. Rptr. at 134 .

22. The three dissenters were Justices Richardson, Manuel, and Clark. $25 \mathrm{Cal}$. 3d at 916-17, 603 P.2d at 56-57, 160 Cal. Rptr. at 139-40 (Richardson, J., concurring and dissenting).

23. CAL. Civ. Proc. CoDE $\S 1021$ (West 1980) provides in pertiment part that "[e]xcept as attorney's fees are specifically provided for by statute, the measure and mode of compensation of attorneys and counselors at law is left to the agreement, express or implied, of the parties . . .."

24. For a discussion of these equitable principles, see text accompanying notes 37-66 infra. 
courts, and by analogy the PUC when it functions as a court, to award attorney fees. Second, Justice Richardson argued that when the legislature adopted section 1021.5 of the California Code of Civil Procedure, which permits attorney fee awards under specified conditions, ${ }^{25}$ it intended to codify and limit the various equitable attorney fee doctrines. $^{26}$ He contended that because section 1021.5 refers only to "court" proceedings, the legislature intended to preclude PUC fee awards. The majority dismissed this argument as well, saying that the legislature's "open-ended" grant of authority to the PUC im section 701 of the Public Utilities Code ${ }^{27}$ negated any suggestion that the legislature meant to restrict the PUC from exercising some equitable powers.

\section{The Decision in the Ratemaking Case}

In contrast to its decision authorizing attorney fees im reparations cases, the majority of the court found that neither the Public Utilities Code nor policy considerations "require, or even permit" the PUC to award attorney fees in ratemaking proceedings. ${ }^{28}$ The court distmguished reparations actions froin ratemaking proceedimgs on the ground that the former closely resemble judicial proceedimgs, while the latter have legislative features, including numerous intervenors, the as-

25. CAL. Civ. Proc. Code $\S 1021.5$ (West 1980) recognizes the private attorney general doctrine for fee awards:

Upon motion, a court may award attorneys' fees to a successful party against one or more opposing parties im any action which has resulted in the enforcement of an important right affecting the public interest if: (a) a significant benefit, whether pecuniary or nonpecuniary, lias been conferred on the general public or a large class of persons, (b) the necessity and financial burden of private enforcement are such as to make the award appropriate, and (c) such fees should not in the interest of justice be paid out of the recovery, if any. With respect to actions mvolving public entities, this section applies to allowances agamst, but not in favor of, public entities, and no claim shall be required to be filed therefor.

26. It is apparently Justice Richardson's contention that by adopting CAL. Crv. Proc. CodE $\$ 1021.5$ (West 1980), which codifies the equitable theory known as the private attorney general doctrine, the legislature imtended to repeal the other equitable attorney fee doctrines. The majority did not address this issue; however, circumstances surrounding the passage of $\$ 1021.5$ contradict the dissent's imterpretation. Justice Richardson seems to concede that $\$ 1021.5$ was enacted in response to the United States Supreme Court decision in Alyeska Pipeline Serv. Co. v. Wilderness Soc'y, 421 U.S. 240 (1975), where the Court refused to adopt the private attorney general theory for use in federal courts. $25 \mathrm{Cal}$. 3d at 916, 603 P.2d at 56, I60 Cal. Rptr. at 139 (Richardson, J., concurring and dissenting). Thus, im adopting $\$ 1021.5$, the legislature extended the power of California courts beyond that of the federal courts. It would be somewhat imcongruous to conclude that at the same time that the legislature extended the California courts' power to award fees under the private attorney general theory, it also intended to revoke the other equitable doctrines. If the legislature had so intended, it would probably have done so $\mathrm{m}$ a clearer fashion. Morcover, California courts have continued to discuss these doctrines with approval after $\S 1021.5$ was enacted, see, e.g., Woodland Hills Residents Ass'n v. City Council, 23 Cal. 3d 917, 593 P.2d 200, 154 Cal. Rptr. 503 (1978), and this has evoked no response from the legislature.

27. Cal. Pub. UtIL. Code $\S 701$ (West 1975). See note 2 supra.

28. 25 Cal. 3d at 911,603 P.2d at 53, 160 Cal. Rptr. at 136. 
similation of a wide variety of public interests, and an outcoine tliat cannot be deemed a clear-cut victory for any single party. ${ }^{29}$ The court also pointed out that reparations are equivalent to judicial relief in that they remedy past injury. In contrast, the charges collected during the ratemaking proceedings and later refunded to customers were akin to a reduction in rates, a legislative product. ${ }^{30}$ The court buttressed its decision not to permit attorney fee awards in rateinaking with a policy argument, explaining that because ratenaking invites liberal public participation, it would be excessively burdensoine, if not impossible, to isolate the individual contribution of each participant. ${ }^{31}$

The court also rejected TURN's arguinent that the PUC's expansive regulatory and rulemaking powers under section $701^{32}$ and its power to set rates under section $728^{33}$ permit the PUC to charge ratepayers public participation costs. The court conceded that public participation in ratennaking was to be encouraged, but considered that a decision authorizing the PUC to award fees to ratemaking participants should he with the legislature, given the "administrative quagmire" that night result from fee claims advanced by numerous parties. ${ }^{34}$

In a dissenting opinion authored by Justice Newman, three justices argued that the PUC's power to award fees extended beyond quasijudicial actions, saying they were not persuaded that fee awards were mappropriate in ratemaking cases. ${ }^{35}$ The dissent pointed out that adversarial "on-the-record" ratemaking procedurally resembles quasijudicial reparations proceedings. The dissent also observed that the elements of ratemaking that the majority labeled quasi-legislative-the multiplicity of parties and the absence of a clear-cut victory for any single party-are also characteristic of many administrative adjudications. The dissent suggested that fee awards should be permitted in any

29. Id. at 909-10, 603 P.2d at 51-52, 160 Cal. Rptr. at 134-35.

30. Id. at 909, 603 P.2d at 51, 160 Cal. Rptr. at 134.

31. Id. at 910,603 P.2d at $52,160 \mathrm{Cal}$. Rptr. at 135 .

The PUC's rules also permit liberal intervention in reparations cases. See text accompanying note 103 infra. Thus, at least theoretically, reparations cases could also attract numerous public participants-particularly now that the court lias directed the PUC to consider attorney fee requests in such cases. The court's prediction that ratemaking will usually attract more participants is, however, probably sound. In a reparations case the ratepayers who have been overcharged would usually have common interests which could be adequately protected by a single representative complamant. In contrast, in ratemaking proceedings, there may be numerous competing interests-for example, commercial customers versus residential customers, urban versus rural consumers, and environmentalists versus industry. Each diverse interest group would probably want to participate to ensure that its views were adequately voiced.

32. Cal. Pub. UTIL. Code $\S 701$ (West 1975). See text accompanying note 14 supra.

33. Cal. Pub. UTIL. Code $\S 728$ (West 1975). See note 4 supra.

34. $25 \mathrm{Cal} .3 \mathrm{~d}$ at $911-12,603$ P.2d at 53,160 Cal. Rptr. at 136.

35. The three dissenters were Chief Justice Bird and Justices Newinan and Tobriner. Id. at 918, 603 P.2d at 57, 160 Cal. Rptr. at 140 (Newman, J., concurring and dissenting). 
"trial-type" proceedings where attorneys perform adversarial functions. ${ }^{36}$

\section{II}

\section{LEGAL BACKGROUND}

\section{A. Judicial Exceptions to the American Attorney Fees Rule}

American courts, in contrast to those of England, do not ordinarily award the prevailing party attorney fees assessed against the loser. Rather, the general "American rule" requires a litigant, win or lose, to bear the cost of his own counsel fees. ${ }^{37}$ In California this rule is codified in section 1021 of the Code of Civil Procedure, which permits attorney fee awards only if authorized by statute or by agreement of the parties. ${ }^{38}$ California courts, however, have recognized three theories justifying exceptions to the American rule, based on the inherent equitable powers of courts: the common fund theory, the substantial benefit theory, and the private attorney general theory. ${ }^{39}$

\section{The Common Fund Theory}

The common fund theory is the oldest and best established of the three common law exceptions to the general American rule. It provides that "one who expends attorney's fees in winning a suit which creates a fund from which others derive benefits, may require those passive beneficiaries to bear a fair share of the litigation costs."40 The policy un-

36. Id. at 919-20, 603 P.2d at 58, 160 Cal. Rptr. at 141 .

37. Alyeska Pipeline Serv. Co. v. Wilderness Soc'y, 421 U.S. 240, 247-57 (1974). For discussion and criticism of the American rule, see Ehrenzweig, Reimbursement of Counsel Fees and the Great Society, 54 CALIF. L. REv. 792 (1966); Goodhart, Costs, 38 YALE L.J. 849 (1929); Kuenzel, The Attorney's Fee: Why Not a Cost of Litigation?, 49 IowA L. Rev. 75 (1963); McCormick, Counsel Fees and Other Expenses of Litigation as an Element of Damages, 15 MinN. L. REv. 619 (1931); McLaughlin, The Recovery of Attorney's Fees: A New Method of Financing Legal Services, 40 Fordham L. Rev. 761 (1972); Comment, Court Awarded Attorney's Fees and Equal Access to the Courts, 122 U. PA. L. Rev. 636 (1974).

38. See note 23 supra.

39. Federal law recognizes a separate equitable ground for awarding fees and costs "when the losing party has 'acted in bad faith, vexatiously, wantonly, or for oppressive reasons . . . ." Alyeska Pipeline Serv. Co. v. Wilderness Soc'y, 421 U.S. 240, 258 (1975) (quoting F. D. Rich Co. v. Industrial Lumber Co., 417 U.S. 116, 129 (1974). Whether bad faith exists as an independent ground for an equitable award of fees in California is an open question. D'Amico v. Board of Medical Examiners, 11 Cal. 3d 1, 27, 520 P.2d 10, 29, 112 Cal. Rptr. 786, 805 (1974).

40. Serrano v. Priest, 20 Cal. 3d 25, 35, 569 P.2d 1303, 1307, 141 Cal. Rptr. 315, 318 (1977) (quoting Quinn v. State, 15 Cal. 3d 162, 167, 539 P.2d 761, 764, 124 Cal. Rptr. 1, 4 (1975)). See Alyeska Pipeline Serv. Co. v. Wilderness Soc'y, 421 U.S. 240, $257-58$ (1974). See generally Dawson, Lawyers \& Involuntary Clients, Attomey Fees from Funds, 87 HARv. L. REv. 1597 (1974). For a summary of the doctrine of unjust enrichment, see $1 \mathrm{G}$. PALMER, THE LAW OF RestrTution $\S 1.1$ (1978). 
derlying this doctrine is preventing unjust enrichment. ${ }^{41}$ Fees are awarded on the rationale that those who benefit from the fund should share the cost of its creation and that this can best be accoinplislied by taxing the fund itself. 42

In applying the common fund exception, courts have imposed additional requirements that aid in the administration of fee awards. First, a fee award is permitted only where the passive beneficiaries derive a inonetary benefit from the fee claimant's efforts. ${ }^{43}$ Second, a "certain or easily calculable" fund of money must exist out of which the fees can be paid. ${ }^{44}$

Courts have also limited the application of the common fund doctrine to prevent it from undercutting the general American rule disfavoring attorney fee awards. The courts have almost uniformly refused to award fees to attorneys who successfully lobby for new legislation, even though the new legislation creates a monetary benefit for otliers. ${ }^{45}$ Similarly, an attorney who persuades a court to adopt a new legal principle that, with stare decisis effect, will permit future litigants to recover monetary funds is not entitled to claim a portion of those funds as attorney fees. ${ }^{46}$

The courts have discussed their rationale for imposing these limi-

41. See Woodland Hills Residents Ass'n v. City Council, 23 Cal. 3d 917, 943, 593 P.2d 200, 214, 154 Cal. Rptr. 503, 517 (1979).

42. Serrano v. Priest, 20 Cal. 3 d at 35 n.5, 569 P.2d at 1307 n.5, 141 Cal. Rptr. at 319 n.5.

43. Id. at 35, 569 P.2d at $1307,141 \mathrm{Cal}$. Rptr. at 319.

44. Id.

45. See Dawson, supra note 40 , at 1611 .

Courts have on rare occasions said that lobbying by lawyers should qualify for an attorney fee award. In Winton v. Amos, 255 U.S. 373, 393 (1921), the Court declared that the common fund doctrine would permit an attorney fee award to lawyers whose congressional lobbying efforts secured allotments of land to Choctaw Indians in Mississippi. This language was dicta, however, because Congress had passed a special statute allowing the lawyers who engaged in these activities to bring actions in the Court of Claims "on the principle of quantum meruit." Id. at 376. See also Louisiana State Mineral Bd. v. Abadie, 164 So. 2d 159, 167-68, 170 (La. Ct. App. 1964) (lumping lobbying services with other activities, including litigation, in coinputing attorney compensation).

46. Dawson, supra note 40, at 1653; Dawson, Lawyers and Involuntary Clients in Public Interest Litigation, 88 HARv. L. Rev. 849, 916 (1975). See, e.g., Cranston v. Hardin, 504 F.2d 566 (2d Cir. 1974) (attorneys argued they were entitled to fee because a Supreme Court decision they secured in prior case "dictated" outcome that preserved fund in succeeding case); Whittier v. Emmet, 282 F.2d 24, 32 (D.C. Cir. 1960), cert. denied, 364 U.S. 935 (1961) (litigation by veterans established right of other veterans to government insurance refunds).

One federal case, Sprague v. Ticomic Nat'l Bank, 307 U.S. 161 (1939), contains dicta indicating that a common fund award may be proper in a case where the claimant's efforts benefit a class through a stare decisis effect. Id. at 167 . This dicta has been criticized by coinmentators as too far-reaching. See Dawson, supra note 40 , at 1610.

In any event, California probably would not follow the Sprague dicta. In Woodland Hills Residents Ass'n v. City Council, 23 Cal. 3d 917, 946-47, 593 P.2d 200, 216-17, 154 Cal. Rptr. $519-$ 20 (1979), the Cahfornia Supreme Court refused to permit an award under the substantial benefit doctrine based on the claimant's efforts to estabhsh a new principle of law that would have stare decisis effect. As the substantial benefit theory is merely an outgrowth of the common fund doc- 
tations only in broad terms. It has been said of claims based on lobbying efforts, for example, that " $[t]$ he assertion of a noncontractual claim for compensation for services rendered in sponsorimg favorable legislation does not deserve prolonged discussion." 47 And courts have expressed similar reluctance to tax the future beneficiaries of a fund created by a new legal primciple: "It is a novel assertion that attorneys who are victorious in one case inay, like the holder of a copyright, claim fees from all subsequent litigants who might rely on it in one way or another." ${ }^{48}$ The latter statement, however, does at least hint at the policy concern that probably underlies these limitations. Courtawarded fees for successful lobbyists would prove a major incursion on the American rule denying recovery of attorney fees. Likewise, awarding fees to attorneys whose victory in one case was used by others in later cases to create a fund would soon echipse the general American rule. It would be an unusual case that did not rely on a legal precedent established in some earlier case.

\section{The Substantial Benefit Theory}

The second nonstatutory exception to the general American rule, the substantial benefit theory, permits the award of fees when "the litigant, proceeding in a representative capacity, obtaims a decision resulting in the conferral of a 'substantial benefit' of a pecuniary or nonpecuniary nature."49 Like the common fund theory, the substantial benefit doctrine rests on the policy of preventing unjust enrichinent of the passive recipients of a benefit obtamed through the fee claimant's efforts. $^{50}$ Unlike the common fund theory, the substantial benefit doctrine does not require that a specific fund be created out of which fees could be awarded. It requires only that the claimant's efforts confer on an ascertamable class a substantial advantage, whether pecuniary or not, sufficiently beneficial to justify shifting the monetary burden of producing that benefit to those who enjoy it. ${ }^{51}$

trine, see D'Amico v. Board of Medical Examimers, 11 Cal. 3d 1, 25, 520 P.2d 10, 29, 112 Cal. Rptr. 786, 804 (1974), the same rule should apply to common fund cases.

47. Whittier v. Emmet, 281 F.2d 24, 32 (D.C. Cir. 1960), cert. denied, 364 U.S. 935 (1961).

48. Woodland Hills Residents Ass'n v. City Council, 23 Cal. 3d 917, 946, 593 P.2d 200, 216,

154 Cal. Rptr. 503, 519-20 (1979) (quoting Cranston v. Hardin, 504 F.2d 566, 580 (2d Cir. 1974)). The Woodland Hills court also pointed out the impracticality of trying to decide which of many attorneys who could claim credit for helping to establish a particular legal principle should be awarded fees. $I d$.

49. Serrano v. Priest, 20 Cal. 3d 25, 38, 569 P.2d 1303, 1309, 141 Cal. Rptr. 315, 321 (1977).

50. Id.; Woodland Hills Residents Ass'n v. City Council, 23 Cal. 3d at 943, 593 P.2d at 214, 154 Cal. Rptr. at 517.

51. See Woodland Hills Residents Ass'n v. City Council, 23 Cal. 3d at 945-46, 593 P.2d at 215-16, 154 Cal. Rptr. at 518-19; Serrano v. Priest, 20 Cal. 3d at 39, 569 P.2d at 1309, 141 Cal. Rptr. at 321. 
As with the common fund doctrine, the courts have formulated several primciples that limit the application of the substantial benefit doctrine. First, awards are proper under this theory only if "concrete" benefits will accrue to an ascertainable class as a result of the fee claimant's efforts. ${ }^{52}$ For example, an action successfully challenging the constitutionahity of giving state einployees time off with pay on Good Friday produces a concrete benefit for state citizens, in the form of future savings of wages forinerly paid when no work was perforned. ${ }^{53}$ In contrast, an action successfully challenging the constitutionality of funding schools with local property taxes would not qualify for an award. In the latter case, any concrete benefit that might ultiinately result-lowered taxes or better education-would not stem from the hitigation itself but would depend entirely on the new financing system the legislature adopted. ${ }^{54}$ The hitigation in the latter case would render a service to the citizens of the state by bringing the state's education financing system into conformity with constitutional equal protection provisions. $^{55}$ But the effectuation of constitutional policy, without inore, is not considered sufficiently concrete to serve as a basis for a fee award under the substantial benefit theory. ${ }^{56}$

Another limitation imposed on the substantial benefit doctrine is that the court must have jurisdiction that will permit it to spread the costs proportionately among the benefited class. ${ }^{57}$ The policy underlying this requirement is that a fee award under this doctrine is not meant to saddle the losing party with the expenses, but rather is intended to prevent unjust enrichment by spreading the cost over the benefited class. $^{58}$ For example, in corporate derivative suits, where the doctrine is frequently employed, ${ }^{59}$ the court can effectively impose fees on all the shareholders who have benefited from the action, even though the court does not have jurisdiction over each individual shareholder, by assessing the fees against the defendant corporation. ${ }^{60}$

Finally, as in the common fund cases, courts have also expressly declined to apply the substantial benefit doctrine where the claimant's

52. Woodland Hills Residents Ass'n v. City Council, $23 \mathrm{Cal} .3 \mathrm{~d}$ at $942-46,593$ P.2d at 21416, 154 Cal. Rptr. at 517-19; Serrano v. Priest, 20 Cal. 3d at 40-42, 569 P.2d at 1310-12, 141 Cal. Rptr. at 322-24.

53. See Mandel v. Hodges, 54 Cal. App. 3d 596, 127 Cal. Rptr. 244 (1st Dist. 1976).

54. Serrano v. Priest, 20 Cal. $3 d$ at 41,569 P.2d at 1311-12, 141 Cal. Rptr. at 323.

55. Id. at 42,569 P.2d at 1312,141 Cal. Rptr. at 323 .

56. Id.

57. Id. at 40 n.10, 569 P.2d at 1310 n.10, 141 Cal. Rptr. at 322 n.10 (quoting Mills v. Electric Auto-Lite, 396 U.S. 375, 393-94 (1970)).

58. Mills v. Electric Auto-Lite, 396 U.S. at 396-97.

59. See, e.g., id.; Fletcher v. A. J. Indus., Inc., 266 Cal. App. 2d 313, 72 Cal. Rptr. 146 (1st Dist. 1968).

60. See Mills v. Electric Auto-Lite, 396 U.S. at 396-97. 
efforts establish a new principle of law that will benefit others for an indefinite period in the future. Although it is an inherent consequence of the doctrine of stare decisis that a legal principle established in one case will benefit later litigants, "the doctrine of stare decisis has never been viewed as a sufficient justification for perinitting an attorney to obtain fees [under the substantial benefit doctrine] froin all those who inay, in future cases, utilize a precedent he has helped to secure."61

\section{The Private Attorney General Theory}

California courts recognize a third exception to the American rule under the private attorney general theory. ${ }^{62}$ Under this theory, a court inay shift a plaintiff's attorney fees to a defendant shown to be acting contrary to important constitutional or statutory policy. ${ }^{63}$ The underlying policy is to encourage the presentation of ineritorious suits vindicating important public policy "by awarding substantial attorney's fees . . . to those who successfully bring such suits, and thereby bring about benefits to a broad class of citizens."64 In evaluating claims for fee awards under the private attorney general doctrine, courts inust consider the strength or societal import of the public policy vindicated by

61. Woodland Hills Residents Ass'n v. City Council, 23 Cal. 3d at 946-47, 593 P.2d at 21617, 154 Cal. Rptr. at 519-20. Accord, Northington v. Davis, 23 Cal. 3d 955, 961,593 P.2d 221, 225, 154 Cal. Rptr. 524, 528 (1979). The same rule applies in federal courts. See Schlcit v. British Overseas Airways Corp., 410 F.2d 261, 262 (D.C. Cir. 1969); Preston v. Unitcd States, 284 F.2d 514 (9th Cir. 1960).

62. Federal courts do not recognize the private attorney general theory. See Alyeska Pipeline Serv. Co. v. Wilderness Soc'y, 421 U.S. 240 (1974). Despite the Suprene Court's view that the theory infringes "on a policy inatter Congress has reserved for itself," $i d$. at 269, the California Supreme Court adopted the theory in Serrano v. Priest, 20 Cal. 3d 25, 43, 569 P.2d 1303, 1313, 141 Cal. Rptr. 315, 324 (1977); ("[T] he fashioning of equitable exceptions . . . to be applied in California is a matter within the sole competence of this court.") Four days before the court announced this decision, the governor signed legislation codifying the private attorney general exception in a form very much like that of Serrano. CAL. Civ. Proc. Code $\$ 1021.5$ (West 1980).

63. Technically, it is still an open question whether the common law principles of the private attorney general theory apply to vindication of a statutory right. That question was left open by Serrano. See 20 Cal. 3d at 46, 569 P.2d at 1314-15, 141 Cal. Rptr. at 326. In a tater attorney fee decision, Woodland Hills Residents Ass'n v. City Council, 23 Cal. 3d 917, 935, 593 P.2d 200, 209, 154 Cal. Rptr. 503, 512 (1979), the court held that a court could award fees for vindication of statutory rights, but it based its decision on a statutory interpretation of CAL. CIv. PROC. CODE $\S 1021.5$ (West 1980). It was thus unnecessary to reach the issue of whether a court's equitable powers alone would permit it to award fees in such cases. The court's analysis of what constitutes an "important right" under $\S 1021.5 \mathrm{seems}$, lowever, to indicate that the court would consider at least some statutory policies to be of sufficient societal import to ineet the requirements of the common law private attorney general theory. See 23 Cal. 3d at 135-38, 593 P.2d at 205-07, 154 Cal. Rptr. at 512-14. See also McDennott \& Rothschild, The Supreme Court of California, 1976. 1977-Forward: The Private Attorney General Rule and Public Interest Litigation in California, 66 CALIF. L. Rev. 138, 141-42 (1978).

64. Serrano v. Priest, 20 Cal. 3d at 43, 569 P.2d at 1312, 141 Cal. Rptr. at 324 (quoting D'Amico v. Board of Medical Examiners, 11 Cal. 3d 1, 27, 520 P.2d 10, 29, 112 Cal. Rptr. 786, 805 (1974)). 
the litigation, the necessity for private enforcement and magnitude of the burden undertaken by the plaintiff, and the number of people standing to benefit from the decision. ${ }^{65}$ Only if the trial court decides that the litigation has resulted in the vindication of an important public policy, that the costs of securing this result "transcend the individual plaintiff's pecuniary interest to an extent requiring subsidization," and that a large number of people are likely to benefit from the decision, may the court exercise its power to award attorney fees on this theory. ${ }^{66}$ These factors are necessary to distinguisl 1 awards under the private attorney general theory, because the notion of substantial benefit, as discussed above, does not extend to such indefinite advantages as the vimdication of important constitutional or statutory policies.

\section{B. Administrative Agency Fee Awards}

In CLAM, both TURN and CLAM argued that they were entitled to fee awards from the PUC. Demands for attorney fee awards from administrative agencies are a corollary to increased public participation before the agencies. Growing concern in recent years that participation in agency proceedings had been too limited, confined largely to representatives of regulated industries ${ }^{67}$ prompted decisions broadening standing and intervention rules to permit greater public participation. ${ }^{68}$ Increased participation, however, has in turn raised the issue of how that participation should be financed. The primaxy concern is that without some form of financing, public representatives will be unable to compete effectively with well-financed, highly organized industry interests in complex, technical administrative proceedings. ${ }^{69}$ One ap-

65. Serrano v. Priest, 20 Cal. 3d at 45, 569 P.2d at 1314, 141 Cal. Rptr. at 325. See McDermott \& Rothschild, supra note 63, at 142.

66. Serrano v. Priest, $20 \mathrm{Cal} .3 \mathrm{~d}$ at 45,569 P.2d at 1314, $141 \mathrm{Cal}$. Rptr. at 325.

67. See, eg., Bonfield, Representation for the Poor in Federal Rulemaking, 67 MICH. L. REv. 511 (1969); Cramton, The Why, Where and How of Broadened Participation in the Administrative Process, 60 GEo. L.J. 525 (1972); Gellhorn, Public Participation in Administrative Proceedings, 81 YALE L.J. 359 (1972); Jaffe, The Effective Limits of the Administrative Process: A Reevaluation, 67 HARv. L. REv. 1105 (1954); Lazarus \& Onek, The Regulators and the People, 57 VA. L. REv. 1069 (1971); Stewart, The Reformation of American Administrative Law, 88 HARv. L. REV. 1667, 168485,1713 (1975).

68. See, e.g., Sierra Club v. Morton, 405 U.S. 727 (1972) (recognizing that noneconomic interests such as "aesthetic, conservational, and recreational" concerns are sufficient to give standing); Association of Data Processing Serv. v. Camp, 397 U.S. 150 (1970) (permitting participation under the Administrative Procedure Act, 5 U.S.C. $\$ \S 551-559$ (1976 \& Supp. III 1979), if the complainant is "arguably within the zone of interest to be protected or regulated" by the agency); Office of Communication of the United Church of Christ v. F.C.C., 359 F.2d 994 (D.C. Cir. 1966) (giving national church organization the right to intervene as a "responsible representative" in an agency proceeding concerning renewal of a television station's license).

69. See Stewart, supra note 67, at 1713-15. 
proach has been an effort by participants like TURN and CLAM to obtain reimbursement for attorney fees.

Most courts have been unreceptive to such attorney fee requests arising out of administrative proceedings. CLAM is the first decision expressly extending authority to an admimistrative agency to award attorney fees as an exercise of the agency's equitable powers. ${ }^{70}$ Most other jurisdictions regard the power to authorize fee awards in cases tried before administrative agencies as an exclusive legislative prerogative and decline to permit agencies to coinpensate participants absent express statutory authorization. ${ }^{71}$ Even before CLAM, however, a handful of courts had recognized exceptions to this general requirewnent for express statutory authorization. ${ }^{72}$

In federal courts, for example, an agency's own interpretation of its authority to award fees under its organic statutes seems to be determinative, although the issue is not settled. In Greene County Planning Board v. Federal Power Commission, ${ }^{73}$ decided by the Second Circuit, a group that had successfully opposed power line construction in hearings before the Federal Power Commission sought fees. The Commission ruled that it had no authority to disburse public funds without express Congressional authorization. The Second Circuit, sitting en banc, upheld this decision, saying express statutory authority was necessary, even though the Coinptroller General had since aimounced that

70. Mountain States Tel. \& Tel. v. PUC, 180 Colo. 74, 502 P.2d 945 (1972) could be read as recognizing an equitable common fund theory. However, in a later decision, Mountain States Tel. \& Tel. v. PUC, 195 Colo. 130, 135, 576 P.2d 544, 547 (1978), the Colorado Supreme Court made clear that the existence of the common fund in the first case "was only an incidental consideration in concluding that the PUC has authority to award attorneys' fees in certain cases justifying such an award."

71. See, e.g., Greene County Planning Bd. v. Federál Power Comm'n, 559 F.2d 1227, 123840 (2d Cir. 1976), cert. denied, 434 U.S. 1086 (1978) (Federal Power Comınission cannot reimburse group successfully opposing powerline constmction); City of Chicago v. Fair Employment Practices Comm'n, 65 Ill. 2d 108, 357 N.E.2d 1154 (1976) (state commission had no power to order City of Chicago to pay attorney fees to woman winning a sex discrimination case); Ohio Pub. Interest Action Group, Inc. v. PUC, 43 Ohio St. 2d 175, 184-85, 331 N.E.2d 730, 736 (1975) (PUC cannot shift attorney fee costs onto soine parties to the proceeding for the bencfit of other partics).

72. For example, in Mountain States Tel. \& Tel. v. PUC, 195 Colo. 130, 576 P.2d 544 (1978), the Colorado Supreme Court held that the PUC could award fees to ratemaking participants. The court based its decision on the conclusion that the state constitution delegated unlimited legislative authority in public utility matters to the PUC unless the legislature took affirmative action to restrict that authority. In City of Wheeling v. Natural Gas Co., 115 W. Va. 149, 175 S.E. 339 (1934), the Public Service Commission was allowed to award attomey fees out of a utility's operation expenses if a participant in ratemaking had "inaterially benefitted" consumers. In two other cases, common fund awards were granted for work done before adininistrative agencies, but the awards were given by courts. Honda v. Mitchell, 419 F.2d 324 (D.C. Cir. 1969); Powell v. Pennsylvania R.R., 267 F.2d 241 (3d Cir. 1959) (award imcluded coinpensation for litigation before the awarding court).

73. 559 F.2d 1227 (2d Cir. 1976) (en banc), cert. denied, 434 U.S. 1086 (1978). 
the agency could reimburse public participants. ${ }^{74}$ Since Greene, lowever, the Department of Justice's legal counsel has advised at least two federal agencies that Greene does not preclude an agency from determining whether its "organic statutes and other relevant statutes" permit a compensation program. ${ }^{75}$ Indeed, two federal district courts have approved reimbursement schemes of federal agencies designed to coinpensate consumer advocates, distinguishing Greene as a case where the agency itself determined that its statutes did not allow reimbursement. ${ }^{76}$ Commentators have also concluded that an agency's own determination of its authority will be dispositive. ${ }^{77}$

The CLAM court, then, confronted a legal tradition im which California courts, but not administrative agencies, exercised wellestabhshed equitable powers to award attorney fees. It also considered a recent series of federal decisions deferring to an agency's own imterpretation of its statutory authority to award attorney fees to public participants, observing that the PUC has disclaimed its authority to fashion a reimbursement plan. Nevertheless, the court decided that the PUC could grant an equitable fee award, although it doubted the authority of the PUC to fashion its own reimbursement plan for public participants. This Note evaluates the court's reasoning on both issues.

III

\section{CRITIQUe of THE Court's ANALYsis}

\section{A. The PUC's Equitable Power to Award Attorney Fees}

The court's decision in CLAM that the PUC has equitable power to award attorney fees in reparations cases under the common fund exception is justified, given the PUC's expansive statutory authority.

74. Id. at 1239. The FPC eventually changed its position to agree with that of the Comptroller General. Its change of position, however, came too late to have any effect on the Second Circuit's deliberations. It occurred after the FPC's authority was transferred to the newly created Federal Energy Regulatory Commission (FERC). See Department of Energy Organization Act, 42 U.S.C. \& 7101 (Supp. III 1979). As respondent to the petition for certiorari, the FERC abandoned the FPC position against the reimbursement and urged the Supreme Court to remand to the Second Circuit in light of its new position. Brief for the FERC at 19, Greene County Planning Bd. v. Federal Power Comm'n, 559 F.2d 1227 (2d Cir. 1976) (en banc), cert. denied, 434 U.S. 1086 (1978) (described in Recent Developments-Administrative Law-Fee Reimbursement for Public Interest Intervenors-Agency Reimbursement of Public Interest Intervenors' Costs Reguires Express Statutory Authorization, 66 GEo. L.J. 931, 931 n.1 (1978)).

75. Letter from John A. Harmon, Assistant Attorney Gencral, Department of Justiee, to Philip Bakes, Jr., General Counsel, CAB (Mar. 1, 1978), quoted in Civil Aeronautics Board's Notice of Proposed Rulemaking, Compensation of Participants im Board Proceedings, 43 Fed. Reg. 14044,14050 (1978).

76. Pacific Legal Foundation v. Goyan, 500 F. Supp. 770 (D. Md. 1980); Cliamber of Commerce v. Umited States Dep't of Agric., 449 F. Supp. 216, 220-21 (D.C. Cir. 1978).

77. Everett, Financial Assistance for Public Interest Group Participation in Environmental Decisionmaking, 10 ENVT'L L. REv. 483 (1980); Recent Developments, supra note 74, at 947. 
The legislature has specifically authorized the PUC to hear reparations cases $^{78}$ and to do all things "necessary and convenient" to the regulation of public utilities, whether or not they are specifically mentioned in the PUC's organic statutes. ${ }^{79}$ The court also has traditionally allowed the PUC to assume equitable powers not specifically granted, if they are "cognate and germane" to its statutory duties. ${ }^{80}$ For example, the PUC may issue injunctions ${ }^{81}$ or direct the creation of a trust fund, ${ }^{82}$ even though no statute expressly gives it this power. Because fee awards will encourage the public to bring rate violations to the attention of the PUC, aiding it in its regulatory role, they should also be considered "cognate and germane" to the PUC's statutory duty to regulate public utilities and to hear reparations cases. ${ }^{83}$

The court's rationale for allowing the PUC to inake common fund fee awards may also permit the PUC to award substantial benefit and private attorney general fee awards. To justify permitting the PUC to make common fund awards, the court poimted out the "significant coincidence of powers" between courts and the PUC, "including those that are equitable in nature." ${ }^{\prime 84}$ The court noted that if the reparations case had been brought in a court, the court would have had equitable jurisdiction to award fees. ${ }^{85}$ It reasoned that to prevent unjust enrichment-the policy underlying the common fund doctrime-the PUC should have equivalent fee award discretion. CLAM does not ex-

\footnotetext{
78. CAL. Pub. Util. Code $\S 734$ (West 1975).

79. Id. $\S 701$.

80. Morel v. Railroad Comm'n, 11 Cal. 2d 488, 81 P.2d 144 (1938).

81. See Kern County Land Co. v. Railroad Comm'n, 2 Cal. 2d 29, 36, 38 P.2d 401, 404 (1934).

82. See People v. Superior Court, 62 Cal. 2d 515, 516, 399 P.2d 385, 386-87, 42 Cal. Rptr. $849,850-51$ (1965) (power to direct that trust fund be created to conserve potential refunds during stay of order lowering rates).

83. Justice Richardson's argument that the PUC is precluded from awarding fees by CAL. CIv. Proc. CODE $\S 1021$ (West 1980), which codifies the general American rule, and by the fact that $\$ 1021.5$ 's codification of the private attorney general theory refers only to "courts" is not convincing. See $25 \mathrm{Cal}$. 3d at 916-17, 603 P.2d at 56-57, 160 Cal. Rptr. at 139-40 (Richardson, J., concurring and dissenting). It is well estabhshed that $\$ 1021$ does not absolutely bar courts from giving fee awards, because their power to award fees coines from their equitable jurisdiction. See Serrano v. Priest, 20 Cal. 3d 25, 34, 569 P.2d 1303, 1306, 141 Cal. Rptr. 315,318 (1977). As the PUC also has equitable jurisdiction, see notes $81-82$ and accompanying text supra, it similarly should not be limited by $\S 1021$-at least not when it decides a case where the requireunents of the judicially created fee awards are met. And even though $\S 1021.5$ refers only to courts, that should not preelude the PUC from granting private attorney general awards. The PUC derives its power to award fees from the common law doctrine adopted in Serrano-not from the statutory authorization in $\S 1021.5$. The common law principles, unlike the statute, are not limited to courts. The same rationale that permits the PUC to apply the common law principles of the common fund doctrine should also permit it to apply the other common law fee doctrines. See text accompanying notes $84-88$ infra.
}

84. 25 Cal. 3d at 906,603 P.2d at 50, 160 Cal. Rptr. at 133.

85. Id. at 907,603 P.2d at 50, 160 Cal. Rptr. at 133 . 
pressly address whether the PUC may also invoke the substantial benefit and private attorney general doctrines. But the court's rationale is sufficiently broad to permit the PUC to grant fees whenever an award would serve the underlying policies of any of the equitable doctrines that would apply were a court hearing the case. ${ }^{86}$

The chief argument in favor of limiting the PUC's fee-award power to the common fund doctrine is that the other two theories may raise more troublesome administrative problems. It should generally be fairly easy to determine under the common fund approach whether a fund has been created by the claimant's efforts. In contrast, in applying the other two theories, the PUC would have to decide whether a "substantial" benefit or an "important" public policy interest wcre present. ${ }^{87}$ As the PUC does not function as a court of general jurisdiction, ${ }^{88}$ it would have hittle basis on which to decide questions of general public pohicy. This objection is minimized, however, by the fact that the only policy questions the PUC would be called on to decide would relate to the regulation of public utilities, ${ }^{89} \mathrm{a}$ field in which it has vast experience. Moreover, the PUC should be able to deal with such administrative problems under its rulemaking powers. It has, for example, adopted rules in another context to determine whether a participant has made a "substantial contribution" to a PUC proceeding. ${ }^{90}$

\section{B. Inadequacy of the Court's Quasi-Judicial and Quasi-Legislative Labels}

Once the court had determined that the PUC possesses sufficient equitable jurisdiction to award fees to reparations complamants, it had to decide whether it could also exercise this authority im other contexts. Given the judicial origin of the three common law attorney fee doctrines, it is not surprising that the CLAM court categorized the PUC's

86. In April 1981, David Wilner received a $\$ 29,550$ attorney fee award for the establishment of a common fund. The commission continued to consider whether Wilner should get an additional fee award, under the private attorney general theory, for establishing that the PUC had the power to award attorney fees. Cal. PUC Decision No. 92914 (Apr. 21, 1981).

The CLAM decision may also permit other state administrative agencies to award attomey fees under the judicially created fee awards doctrines. In $C L A M$, the PUC's power to award fees was based on (1) the PUC's broad organic statute, (2) express statutory authority to enforce the law as a court would, and (3) equitable authority. Other agencies with similarly broad powers should also be able to award fees under the CLAM rationale.

87. See notes 51, 64-65 and accompanying text supra.

88. The PUC is not a constitutionally established judicial department. See CAL. Const. art. 6.

89. The PUC's powers are limited to areas "cognate and germane to the regulatiou of public utilities." Morel v. Railroad Comm'n, 11 Cal. 2d 488, 492, 81 P.2d 144, 146 (1938).

90. See Cal. PUC Decision No. 91909 (June 17, 1980); 20 CAL. AdMIN. Code $\$ 76.06$ (Aug. $16,1980)$. 
activities as judicial or nonjudicial in justifying its decision to pernit fee awards in some proceedings but not others. However, the "salient differences" 11 between the proceedings the court labels quasi-judicial and those it calls quasi-legislative do not always obtain.

The court labeled reparations actions quasi-judicial, noting that they resemble court proceedings in several respects: the procedures parallel those of courts, the parties are clearly identified as plaintiff and defendant, the PUC finds facts and applies rules of law to those facts, and the PUC renders a decision in each case, adjudicating vested interests, with clear winners and losers. ${ }^{92}$ In contrast, the court found ratemaking to be quasi-legislative in character because of the presence of legislative features: numerous intervenors represent a wide variety of public positions, the PUC assimilates these views into a composite "public interest," and no clear-cut victory results for any single party ${ }^{93}$ These differences, however, are generalizations not applicable to many PUC proceedings; they will not be dispositive in every case. Moreover, it is open to question whether the putative differences cited by the court serve to differentiate PUC proceedings in a manner that furthers the pohicies of equitable attorney fee awards.

The procedures followed in a PUC action cannot serve as an adequate criteria on which to base a fee award decision. Both ratemaking and reparations actions require procedures that largely parallel those of courts. The PUC has adopted a "uniform . . . procedure for all its substantive activities," 94 leading a former senior counsel to the Commission to comment that "even im rate proceedings there is an adversary, judicial aspect despite the fondness of the commentators to label them legislative in nature." 95 In ratemaking hearings, just as in reparations proceedings, participants are allowed to subpoena witnesses, ${ }^{96}$ produce evidence, ${ }^{97}$ take depositions, ${ }^{98}$ and cross-examine witnesses. ${ }^{99}$ In both, the PUC's decision must be made from the record and must be summarized in findings developed from the hearing. ${ }^{100}$ In either type of proceeding, after rehearing or demal of rehearing, a party nay ap-

91. 25 Cal. 3d at 909, 603 P.2d at 51, 160 Cal. Rptr. at 134.

92. Id. at 908,603 P.2d at 51,160 Cal. Rptr. at 134.

93. Id. at 909, 603 P.2d at 52, 160 Cal. Rptr. at 135 .

94. Lakusta, Operations in an Agency Not Subject to the APA: Public Utilities Commission, 44 Calif. L. Rev. 218, 219 (1956).

95. Id. at 233.

96. 20 CAL. ADMIN. CODE $\S \S 59-61$ (July 23, 1977).

97. CAL. Pub. UTIL. Code $\S 1705$ (West Supp. 1981); 20 CAL. Admin. Code $\$ \$ 64-66$ (July 23, 1977), $\$$ 67-74 (Aug. 16, 1980).

98. Cal. Pub. Util. CODE $\S 1794$ (West 1975).

99. Telephone interview with John Mallory, Assistant Chief Administrative Law Judge, Public Utilities Commission, San Francisco, California (Apr. 13, 1981).

100. Cal. Pub. Util. Code $\S 1705$ (West Supp. 1981). 
peal the PUC's decision to the California Supreme Court. ${ }^{101}$ Thus, if the type of procedures employed determines whether a fee award is proper, there is no basis on which reparations actions can be distinguished from ratemaking.

Nor should the mere presence of the characteristics the court labels quasi-legislative-numerous parties, an outcome representing composite public interests, and no clear-cut winners or losers-automatically foreclose consideration of an attorney fee request. Reparations proceedings cannot always be distimguished from ratemaking on the basis of the number of parties involved. While it is generally true that reparations actions will tend to have fewer participants than ratemaking, this is not always true. Some ratemaking proceedings involve relatively few participants. ${ }^{102}$ Conversely, because of the liberal intervention rules applicable to reparations proceedings, ${ }^{103}$ numerous parties could be joined in a reparations action. ${ }^{104}$

Moreover, much modern litigation in the courts is based on the "public interest" adjudicatory nodel described by Professor Chayes, ${ }^{105}$ and is characterized by the very features the court labels quasilegislative. As Professor Chayes points out, liberal jomder and intervention rules have made multi-party lawsuits common. ${ }^{106}$ Under the public litigation model, the court does not simply remedy private injuries but must often fashion its decrees to take into account many competing social interests, making it difficult to discern clear winners or losers. ${ }^{107}$ Despite the presence of these legislative qualities, it is not

101. Id. \& 1756 (West 1975).

102. See, e.g., Decision No. 89112,84 Cal. PUC 125 (1978) where General Telephone Company of California asked for an imcrease im telephone answering service rates. The only participants were attorneys for General Telephone, an attorney for an organization protesting the rate increase, and the PUC staff.

103. 20 Cal. Admin. Code $\S 53$ (Sept. 28, 1974).

104. This Note does not argue that problems in deciding the contributions of parties are as severe $\mathrm{m}$ court proceedings as in legislative proceedings. There is a spectrum of possibilities for multiparty involvement in each. Admittedly, that spectrnm is narrower in judicial proceedings, where multiparty involvement occurs less often and involves fewer separate issues than in legislative hearings. See note 31 supra. The potential for problems in deciding each party's contribution is therefore less in a judicial proceeding. These realities cannot be ignored, but at the same time they do not hold true in all cases. Therefore, they should not be dispositive of the attorney fee award issue.

105. Chayes, The Role of the Judge in Public Law Litigation, 89 HARv. L. Rev. 1281 (1976).

106. Id. at 1289-92.

107. Id. at 1292-96. According to Chayes, the increased use of equitable relief, in contrast to more traditional damage remedies, results in decrees that, in some respects, resemble legislation. Injunctive rehief, says Chayes, is not just oriented toward a closed set of consequences, but involves a "controversy about future probabilities." Id. at 1292. And fashioning the rehef may involve consideration of strangers' interests when a decision on the issue has consequences for groups of similarly situated individuals. When the lawsuit ends in this type of judicially fashioned decree, "it is not very inuch of a stretch to see it as, pro tanto, a legislative act." Id. at 1297. Some adjudications, then, resemble legislative decisionmaking and involve the kind of composite "pub- 
unusual for courts to award attorney fees in actions that fit Professor Cliayes' public litigation inodel. ${ }^{108}$ Thus, the mere fact that a PUC proceeding has some of the features the court labels quasi-legislative slould not be dispositive of the question whether participants deserve fee awards.

The line between quasi-judicial and quasi-legislative proceedings is also blurred when a ratemaking proceeding-labeled quasilegislative by the court-involves subissues that are resolved in a manner the court has labeled quasi-judicial. The telephone momitoring issue in $C L A M^{109}$ is illustrative. The PUC's decision that the monitoring practice was unconstitutional meets eacl of the criteria of the court's judicial model. There was a complamant (TURN) and a defendant (Pacific Teleplione). ${ }^{110}$ The PUC found the facts and applied rules of law (the state constitution) ${ }^{111}$ to those facts. It rendered a decision adjudicating vested interests (the customers' right to privacy), ${ }^{112}$ and there was a clear prevailing party (TURN) and a clear loser (Pacific Telephone). ${ }^{13}$ Nevertheless, the court, having characterized the entire raternaking proceeding as quasi-legislative, did not look beneath the label to determine whether an attorney fee award would serve the pohcies underlying the judicial attorney fee doctrines. Yet, had the issue arisen in a separate proceeding ${ }^{114}$ that could have been labeled quasijudicial, it might have led to a fee award under the court's test.

The final sliortcoming of the court's test is that it may inake attorney fee decisions turn on a label-quasi-judicial or quasi-legislative-

lic interest" that, according to the court, goes into PUC ratemaking. Consequently, clear winners and losers may be liard to find even in some court proceedings.

108. See, e.g., NAACP v. Allen, 340 F. Supp. 703 (M.D. Ala. 1972), aff d, 493 F.2d 614 (5th Cir. 1974) (awarding fees in suit where court enjoimed racial discrimination in hiring state troopers); Jinks v. Mays, 350 F. Supp. 1037 (N.D. Ga. 1972) (fees granted in civil rights action declaring nontenured teachers eligible for maternity leave). See generally Dawson, supra note 46.

109. See Decision No. 88232, 83 Cal. PUC 149 (1977).

110. TURN did not file an official complaint, but raised the issue of monitoring in the course of its participation in the rate learing. TURN could lave filed a separate complaint on the monitoring issue. Decision No. 88232, 83 Cal. PUC 149, 181 (1977), See CAL. PUB. UTIL. CODE $\S 1702$ (West 1975) (rules for filing complaints).

111. CaL. Const. art. $1, \S 1$ protects the right of privacy.

112. The PUC's jurisdiction was based on CAL. PuB. UTiL. Code $\$ 7906$ (West 1965). Under CAL. Const. art. $3, \S 3.5$, the PUC does not have authority to declare statutes unconstitutional, but that restriction does not affect the enforcement of its own rules or its competence to examine evidence offered before it in light of constitutional standards. Goldin v. PUC, $23 \mathrm{Cal}$. 3d 638, 65354, 592 P.2d 289, 298, 153 Cal. Rptr. 802, 811 (1979).

113. The PUC found that Pacific Telephone's monitoring practices violated the customers' right to privacy because customers were not warned that their conversations might be momitorcd. The PUC ordered Pacific Telephone to give notice in teleplione books of its mouritoring practices. Decision No. 88232, 83 Cal. PUC 149, 161-65 (1977).

114. Indeed, at the end of the hearing, the PUC recommended that issues like the nonitoring issue be heard in separate complaint proceedings in the future. Id. at 181 (1977). 
applied by a different court facing issues entirely different from the questions of whether an attorney fee award would be proper. Federal case law deinonstrates that courts may consider agency proceedings quasi-legislative in character for some purposes but quasi-judicial for others. For example, in Prentis v. Atlantic Coast Line Co. ${ }^{115}$ the Umited States Supreme Court focused on the prospective nature of rateinaking and said "the establishment of a rate . . . is an act legislative, not judicial in kind . . ."116 Almost thirty years later, however, the Court in Morgan v. United States, ${ }^{117}$ faced with the question of whether ratemaking should be considered legislative or judicial in character for due process purposes, reasoned that ratemaking is a "contest with the Government in a quasi-judicial proceeding." 118 These conflictimg lines of authority demonstrate that ratemaking contams both legislative and judicial elements and that the label a court adopts depends on the underlying issue involved in the case before it. The CLAM test is thus flawed im that it permits the PUC to base its attorney fee decision on a label developed in an entirely different legal context. ${ }^{119}$ The court should have required the PUC to look behind the labels and inquire whether the policies that support the judicial attorney fee doctrines would be served by awarding a fee in the present case. ${ }^{120}$

115. 211 U.S. 210 (1908).

116. Id. at 226 .

117. 304 U.S. 1 (1938).

118. Id. at 18. See also Morgan v. United States, 298 U.S. 468, 479-80 (1936) (ratemaking proceeding has both legislative and judicial characteristics).

119. CLAM thus places a premium on applying one label rather than another. Public participants are given a strong incentive to scour the case law for earlier decisions labeling the proceedings quasi-judicial. See, e.g., Environmental Defense Fund's Memorandum of Points and Authorities Re: Attorney Fees and Expert Witness Costs, PUC Application No. 59308, at 7-8 (Mar. 23, 1981). (Environmental Defense Fund's application for attorney fees resulting from its participation in hearings on the application of Southern California Edison Co. and Pacific Gas and Electric Co. for a certificate of public necessity to construct six coal-fired steam electric generating units). In contrast, if the utility opposes a fee award, it has an equally strong incentive to label the proceedings quasi-legislative. As neither label demonstrates why or when fee awards are appropriate, only continuing confusion and litigation can result.

120. Federal administrative law is also tending to examine proceedings according to their various functions, rather than labeling them according to broad categories for purposes of deciding, e.g., what procedures are appropriate. According to Professor Davis:

The movement in the thinking of both judges and administrators is away from the idea that adjudication calls for one procedure and that rulemaking calls for another procedure. The movement is toward the idea that a plurality of procedures is necessary for adjudication, that a plurality of procedures is necessary for rulemaking, and that some of the procedures in adjudication are the same as some of the procedures in rulemaking. Courts now tend to look to the particular task that an agency is performing in an adjudication or in rulenaking in determining what is the required procedure.

2 K. Davis, Administrative Law Treatise $\S 10: 5$, at 324 (2d ed. 1979) (einphasis in original).

The PUC does not use generalized labels to decide what type of procedures are appropriate in ratemaking. Even though California case law labels ratenaking as "quasi-legislative," when the PUC holds rate hearings it employs trial-type proceedings, permitting discovery, crossexamination of witnesses and submission of briefs. See text accompanying notes 94-101 supra. 
The problem with the court's analysis, then, is that the court imjected two unreliable factors-the procedures the PUC uses and the label attached by a prior court-into what should be a straightforward mquiry into whether a fee award would serve the policies underlying the attorney fee doctrines. The following section will propose an alternative analysis based on those policies.

\section{IV}

\section{A Proposed Approach to Administrative Attorney FEE AWARDS}

Although the CLAM majority's quasi-judicial/quasi-legislative distimction is not an adequate standard for determining when the PUC should award fees, a better approach is available. This Note proposes that the PUC analyze a request for an attorney fee award as a court would, first considering whether the required elements of any of the three common law attorney fee doctrines are present and then determining whether the policies underlying the attorney fee doctrines would be served by permitting an award. This approach would ensure that the PUC would award fees where important policy concerns warrant them. At the same time, requiring the PUC to adhere to the saine strict standards courts must observe would ensure that the exceptions do not expand to eclipse the general American rule against attorney fees. The proposed analysis can be illustrated by applying it to the issues in CLAM.

\section{A. Application of the Proposed Approach to the CLAM Reparations Proceedings}

The court correctly concluded that attorney fees should be awarded under the common fund theory in the CLAM reparations action. The common fund theory requires the presence of the following elements: (1) passive beneficiaries must derive a pecuniary benefit from the claimant's efforts and (2) the claimant's efforts must create or preserve a certaim or easily calculable fund of money out of which the fees can be paid. Both elements were present in the CLAM reparations case. First, the California public was the passive beneficiary of the $\$ 400,000$ settlement fund. ${ }^{121}$ Second, as the PUC had earher declined to investigate CLAM's charges, it is clear that the fund resulted from CLAM's efforts. The policy underlying the common fund theorypreventing unjust enrichment-is also served by awarding CLAM its

121. A settlement can be considered a "benefit" in determining the propriety of a fee award. See Northington v. Davis, 23 Cal. 3d 955, 960 n.2, 593 P.2d 221, 224 n.2, 154 Cal. Rptr. 524, 527 n.2 (1979). 
attorney fees. Awarding CLAM fees out of the $\$ 400,000$ spread the cost of the litigation to the persons benefiting from it - the pubhic-who would otherwise pay nothing for the benefit.

\section{B. Application of the Proposed Approach to the TURN Ratemaking Proceedings}

In the ratemaking proceedings, TURN claimed fees with respect to its contribution to three issues: the monitoring issue, the PUC's illegal nodification of its prior decision, and the decision on Pacific Telephone's general rate application that resulted in custoner refunds. The court's analysis treated all these issues under the ratemaking rubric once it classified the entire proceeding as ratemaking, and thus found fee awards inappropriate. In contrast, the proposed approach would consider each issue separately to determine if a fee award would meet the criteria and policies underlying the attorney fee doctrines. ${ }^{122}$

\section{The Monitoring Issue}

TURN was the only party to challenge Pacific Telephone's unconstitutional momitoring of customer calls, which ultimately resulted in the PUC ordering Pacific Telephone to change its practices. TURN could not qualify for an award under the common fund theory, because no pecuniary benefit or common fund was created. ${ }^{123}$ Likewise, the substantial benefit theory would not apply, as vindicating a constitutional right does not satisfy the doctrinal requirement of a "concrete" benefit. ${ }^{124}$

TURN's victory on the momitoring issue, however, seems to ineet the requirements of the private attorney general theory. ${ }^{125}$ TURN enforced an important constitutional right of a large number of Pacific Telephone's custoners. The financial burden on TURN was out of proportion to any benefit its members alone derived. An award would permit the fees to be shifted to Pacific Telephone, the party found to be acting contrary to constitutional policy. ${ }^{126}$ Private enforcement arguably was not necessary because the PUC could have taken administrative action to protect the rights asserted by TURN. ${ }^{127}$ But the PUC had not acted, even though Pacific Telephone's monitoring practice

122. A court may apportion attorney fee awards among separate issues. See Woodland Hills Residents Ass'n v. City Council, 23 Cal. 3d 917, 942, 593 P.2d 200, 213, 154 Cal. Rptr. 503, 516 (1979).

123. See text accompanying note 43 supra.

124. Woodland Hills Residents Ass'n v. City Council, 23 Cal. 3d at 944-45, 593 P.2d at 21516, 154 Cal. Rptr. at 518-19.

125. See notes $62-65$ and accompanying text supra.

126. See note 63 and accompanying text supra.

127. Cal. Pub. Util. Code $\$ 1702$ (West 1975). 
had existed for some time. Thus, each of the doctrinal requirements of the private attorney general doctrine was present. Moreover, the policy concerns that support the doctrine would be served by a fee award, because awards for attorney fees would encourage others to bring illegal activity by utilities to the attention of the PUC. While encouraging such complaints could increase the administrative burdens of the PUC, an abundance of coinplaints of illegal activity by utilities is not an evil to be guarded against, but an aid to PUC enforcement that sliould be encouraged. If unjustified charges are inade, the PUC can dismiss them, ${ }^{128}$ and it has, in any case, discretion to award fees based on the significance of the party's efforts.

\section{The PUC's Illegal Modification of its Order}

TURN also claimed fees for successfully challenging the PUC's unlawful modification of its earlier rate decision. An award under the common fund theory would not be proper: no fund was created, nor did a pecuniary benefit materialize. Nor could an award be sustained under the substantial benefit theory. The only benefit derived froin TURN's action was the effectuation of the PUC's statutorily dictated procedural rules. Standing alone, such an imtangible benefit is imsufficient to justify an attorney fee award under the substantial benefit theory. ${ }^{129}$

However, the court should have directed the PUC to consider whether fees would be appropriate under the private attorney general theory. The need for private enforcement is readily apparent, as the PUC, by acting illegally, demonstrated that it was not policing itself. And TURN's costs in hitigating the issue exceeded its individual stake in the matter. ${ }^{130}$ Whether TURN's efforts satisfied the requirements that the action vindicate "important" public policy and benefit a significantly large number of people ${ }^{131}$ is inore probleinatic. When a court considers an attorney fee award, it must determine whether the right is sufficiently "important" to justify a fee award; enforceinent of "any" statutory right will not automatically qualify. ${ }^{132}$ The PUC might not

128. See 20 Cal. Admin. Code $\$ 56$ (Sept. 28, 1974).

129. Woodland Hills Residents Ass'n v. City Council, 23 Cal. $3 \mathrm{~d}$ at 947,593 P.2d at 217,154 Cal. Rptr. at 520 (1979).

130. See id. at 941,593 P.2d at 213, 154 Cal. Rptr. at 516.

131. See text accompanying notes 65-66 supra.

132. Woodland Hills Residents Ass'n v. City Council, 23 Cal. 3d at 935, 593 P.2d at 209, 154 Cal. Rptr. at 512. It is questionable whether vindicating a statutory right would ever be a suffcient basis for a PUC award. It is also not settled whether the common law principles of the private attorney general theory imclude the power to award fees on the basis of vindication of statutory policy. See note 63 supra. The statutory version of the private attorney general doctrine, CAL. Crv. PROC. CODE $\$ 1021.5$ (West 1980), has been interprcted to permit fee awards for vindication of statutory rights. Woodland Hills Residents Ass'n v. City Council, 23 Cal. 3d at 935-38, 
have found correction of its violation of a procedural rule sufficiently important to justify a fee award. Likewise, it might not have found that correction of the PUC's procedural violation benefited a sufficient number of persons to justify a fee award. ${ }^{133}$ But at least it should have considered these issues. ${ }^{134}$

\section{The Decision Partially Eliminating SMRT}

TURN's final attorney fee claim was based on its participation in the hearings on Pacific Telephone's general rate apphication that resulted in a decision partially eliminating SMRT. During the hearings the PUC had permitted Pacific Telephone to collect SMRT charges, subject to potential refund. ${ }^{135}$ TURN claimed that the refunds constituted a fund out of which the PUC should award fees under the cominon fund theory. ${ }^{136}$

Although the refunds did constitute a fund from which Pacific Telephone's customers derived a monetary benefit, a fee award would not be appropriate. Courts have limited the common fund doctrine, refusing to compensate attorneys for their successful lobbying efforts or for the future effects of new legal principles they establish, even though the new rule creates a monetary benefit for others. ${ }^{137}$ These limitations ought to apply in the context of administrative fee awards as well. The

593 P.2d at 209-11, 154 Cal. Rptr. at 512-14. It is uncertain, however, whether the PUC could award fees under $\S 1021.5$, as it refers only to "courts."

133. In Woodland Hills, the court expressly left open the question whether alteration of illegal government practices would benefit a sufficient number of persons to qualify for a fee award. 23 Cal. 3d at 939-41, 593 P.2d at 212-13, 154 Cal. Rptr. at 515-16.

134. Under the principles enunciated in Woodland Hills, the trial court must make the initial determination whether the criteria for awarding attorney fees are satisfied. Id. at 948, 593 P.2d at 217-18, 154 Cal. Rptr. at 520-21. As the PUC assumes the functions of the trial court in these matters, it should make the initial determination.

135. Consumers Lobby Against Monopolies v. PUC, 25 Cal. 3d 891, 910, 603 P.2d 41, 52, 160 Cal. Rptr. 124, 135 (1979).

The charges are collected subject to refund because the rates are not yet final. If the PUC finally decides to lower the rates, the excess charges collected during the rehearing process will be refunded to ratepayers.

136. Petition for Writ of Review by TURN, at 28-29, CLAM v. PUC, 25 Cal. 3d 891, 603 P.2d 41, 160 Cal. Rptr. 124 (1979).

While it might also be argued that the ratepayer's future cost-savings constituted a fund for fee award purposes, this theory is undercut by the rcquirement that the fund be certain or easily calculable. As it would be inipossible in many cases to determine whether the custoner's future savings resulted because of the rate reduction or because of reduced nsage, see California Mfrs. Ass'u v. PUC, 24 Cal. 3d 836, 840-41, 598 P.2d 836, 838, 157 Cal. Rptr. 676, 678 (1979), it wonld not be possible to easily calculate the fund created by the rate reduction. Future cost savings are also unpossible to calculate, because it cannot be known how long a rate reduction will last. The PUC is free to change the rate at any time, provided that it makes appropriate findings. See City of Los Angeles v. PUC, 15 Cal. 3d 680, 707, 542 P.2d 1371, 1389, 125 Cal. Rptr. 779, 797 (1975); Cal. Pub. UTIL. Code $\S 1708$ (West 1975).

137. See text accompanying notes $45-48$ supra. 
PUC assumes judicially developed powers, but it must accept them with their policies and restrictions or it is doing more than behaving as a court would. The courts' chief policy reason for limiting the common fund exception-to keep it from swallowing the general rule against fee awards-applies as forcefully to administrative awards in ratennaking.

In CLAM the fund existed because the PUC adopted a new rule, one that partially eliminated SMRT and thereby reduced rates. The fund was created when Pacific Telephone refunded the excess charges collected before the rates were finalized. Had the PUC declined to adopt the new rule, the customers would have received no refund; the former rate was not illegal, and a utility cannot be sued for charging a rate legally set by the PUC. ${ }^{138}$ If TURN is to be credited with responsibility for creating or preserving the fund, then, it would have to be because it actively participated in the hearings that led to the adoption of a lower rate for the future, not because it rectified an illegal rate charged in the past. ${ }^{139}$ Thus, awarding a fee to TURN to compensate it for participating in the hearings would be equivalent to rewarding an attorney for lobbying for new legislation or helping to establish a new legal principle with stare decisis effect. The common fund theory has never been viewed as extending this far. ${ }^{140}$

TURN also claimed fees under the substantial benefit doctrine for

138. See City of Los Angeles, v. PUC, 7 Cal. 3d 331, 356-57, 497 P.2d 785, 803-05, 102 Cal. Rptr. 313, 332-33 (1972); CAL. Pub. UTIL. COde $§ 734$ (West 1975).

The policy supporting the rule that the utility cannot be ordered to make refunds if it charges no more than the rate legally approved by the PUC is to give the utility a final rate structure so that it can adjust its financial and operational plans. See Comment, "Basic Findings" and Effective Judicial Review of the California Public Utilities Commission, 13 U.C.L.A. L. REv. 313 (1966).

In one situation the utility may be required to make refunds when it has charged only the amount directed by the PUC. When rate increases are based on increased costs (such as fuel costs), and the increased costs were either overestimated or misallocated among customers, the utility inay be required to refund the increases. According to the court, such rate adjustments based on changing costs do not involve true ratemaking and are thus not subject to the rule prohibiting retroactive ratemaking. California Mfrs. Ass'n v. PUC, 24 Cal. 3d 251, 261, 595 P.2d 98, 103, 155 Cal. Rptr. 664, 669 (1979); Southern Cal. Edison Co. v. PUC, 20 Cal. 3d 813, 817-19, 576 P.2d 945, 946-48, 144 Cal. Rptr. 905, 906-08 (1978).

139. It would be an entirely different situation had TURN been challenging the legality of the PUC's new rate structure. See, eg., Washington Gas Light Co. v. Baker, 190 F.2d 29 (D.C. Cir. 1951), where a consumer group contested an increase in gas rates. During the proceedings, the court ordered the higher rate collected subject to refund. After lolding that the higher rate was illegal because the findings were insufficient to support the PUC's conclusion that the new rate was reasonable, see Washington Gas Light Co. v. Baker, 188 F.2d 11 (1950), cert. denied, 340 U.S. 952 (1951), the court awarded the consumer group attorney fees out of the accumnlated excess payments. $190 \mathrm{~F} .2 \mathrm{~d}$ at 33 .

Washington Gas should be distinguished from the situation in CLAM. In the former case, the attorney remedied a violation of the consumer's right to have the PUC set reasonable fees. In contrast, TURN simply persuaded the PUC to set a lower rate; it did not establish, or even contend, that the existing rate was illegal.

140. See notes $45-46$ and accompanying text supra. 
its participation in the ratemaking proceedings, on the theory that the lower rates constituted a substantial benefit to the ratepayers. ${ }^{141}$ Even if one concedes that lower rates were a "concrete" benefit and that the PUC could spread the costs proportionately among the benefited ratepayers by charging shightly higher rates to pay for the fee award, ${ }^{142}$ TURN still would not qualify for an award under the substantial benefit doctrine. As with the common fund theory, courts have refused to apply this doctrine in cases where the only benefit derived is new legislation or the prospective effect of a new legal rule. ${ }^{143}$

Stretching the common fund and substantial benefit doctrine to coinpensate attorneys who participate in ratemaking hearings would seriously undermine, in the administrative context, the general American rule denying recovery of counsel fees. Once the common fund or substantial benefit doctrines are applied in this context, there would be no logical reason for not applying them whenever an attorney helps persuade a court or legislature to adopt a new legal rule that will benefit others. If a rate reduction unjustly enriches ratepayers unless they pay attorney fees to ratemaking participants, the same could be said of any new law or judicial precedent that creates concrete benefits for an ascertainable class. The American rule may itself be subject to criticism. ${ }^{144}$ But while the rule stands, it should not be evaded by broad expansion of the equitable exceptions that have been fashioned to apply only to a narrow class of particularly compelling cases.

Nor can a rate reduction ordinarily qualify a participant for a fee award under the private attorney general theory. Fee awards under the private attorney general theory are equitable fee-shifting devices. The victor's fees are shifted to the party found to be in violation of an existing statutory or constitutional right. ${ }^{145}$ But even if the PUC reduces rates, this does not mean anyone violated statutory policy. The utility is not accused of violating the old tariff; the tariff is merely being changed. ${ }^{146}$ Neither is the PUC in violation. Tariff reductions do not estabhish that the old tariff was unreasonably set by the PUC. There is not a single reasonable rate but a range of possible reasonable rates. ${ }^{147}$ A lowered tariff may only indicate that the PUC is taking into account

141. Petition for Writ of Review by TURN, supra note 136, at 30-33.

142. See text accompanying notes $52-60$ supra.

143. See note 61 and accompanying text supra.

144. See Dawson, supra note 40 , at $1600-01$.

145. See note 60 and accompanying text supra.

146. See notes 138-140 and accompanying text supra.

147. See City of Los Angeles v. PUC, 7 Cal. 3d 331, 348, 497 P.2d 785, 798, 102 Cal. Rptr. 313,326 (1972). 
changed circumstances. ${ }^{148}$ As there is no wrongdoer to whom fees can be shifted, the private attorney general theory is inappropriate.

One might argue that a participant's contribution to the formulation of a reduced rate vindicates the ratepayer's statutory right to have the PUC set "reasonable" rates, ${ }^{149}$ and thereby qualifies the participant for a fee award. This argument has two flaws. First, the ratepayer's statutory right is to have the PUC set, not the optimal, but a reasonable rate. To assume that the fee clamiant's participation "vindicated" the ratepayers' right to reasonable rates presupposes that, without the claimant's participation, the PUC would have set an unreasonable rate. Such a presumption would be contrary to the strong presumption of the vahidity and correctness of Commission decisions. ${ }^{150}$ As a political reality, it may be true that consuuners are not well represented before the PUC without the participation of public interest groups like TURN. ${ }^{151}$ As a legal matter, however, TURN's absence, while perhaps a loss to consumers, would not necessarily make the PUC's rate decisions unreasonable, only less favorable. Thus, TURN's presence camiot be said to have vindicated a constitutional or statutory right. ${ }^{152}$

The analysis thus far leads to the conclusion that the equitable

148. See Pacific Tel. \& Tel. Co. v. PUC, 62 Cal. 2d 634, 656-57, 401 P.2d 353, 366-67, 44 Cal. Rptr. 1, 14-15 (1965).

149. CaL. Pub. Util. Code $\S 728$ (West 1975) ("the commission shall determine and fix, by order, the just, reasonable, or sufficient rates"). See Decision No. 87962, 82 Cal. PUC 725, 755 (1977) ("[R]ates are just and reasonable if they enable a utility to operate successfully, maintain its financial integrity, attract capital, and compensate investors for risks assumed.").

150. There is a strong presumption favoring the validity of a PUC decision. Its findings of fact, for exaunple, are not open to attack for insufficiency if they are supported by any reasouable construction of the evidence, and when evidence is preseuted from which conflicting inferences can be drawn, the Commission's findings are final. Toward Utility Rate Nonnalization v. PUC, 22 Cal. 3d 529, 537-40, 585 P.2d 491, 495-97, 149 Cal. Rptr. 692, 696-98 (1978). When a petitioner claims a federal constitutional violation, however, the court is instructed to exercise its imdependent judgment on the law and facts, CAL. PUB. UTIL. CODE $\$ 1760$ (West 1975), although in practice the supreme court generally treats the PUC with considerably more defereuce than $\S 1760$ would imply. See Comment, supra note 138, at $316 \&$ n.12, $317 \&$ nn.13, 15.

151. The PUC has admitted that it cannot adequately represent all segmeuts of the public. Cal. PUC Decision No. 91909, slip op. at 5-6 (June 17, 1980). In disposing of a prior appeal by TURN, however, the supreme court expressed its belief that the PUC adequately represented the public in the SMRT hearings. See Toward Utility Rate Normalization v. PUC, 22 Cal. 3d 529, 541-42, 585 P.2d 491, 497-98, 149 Cal. Rptr. 692, 698-99 (1978).

152. See Note, Federal Agency Assistance to Impecunious Intervenors, 88 HARv. L. Rev. 1815, 1825 (1975).

Had TURN actually demonstrated that the PUC had acted unreasonably or illegally in setting the rates, it would have had a stronger argument for a fee award nnder the private attorney general theory. The PUC's ratemaking decisions are occasionally reversed because the PUC's findings and evidence are insufficient to support the decision, e.g., California Mfrs. Ass'n v. PUC, $24 \mathrm{Cal}$. 3d at $260,595 \mathrm{P} .2 \mathrm{~d}$ at $102,155 \mathrm{Cal}$. Rptr. at 668 , or because the rate is based on faulty reasoning, e.g. , City of Los Angeles v. PUC, 7 Cal. 3d at 337-48, 353-54, 497 P.2d at 790-98, 80102 , 102 Cal. Rptr. at 318-26, 329-30. In such cases, the petitioner can more plausibly claim to have vindicated the statutory right to reasonable fees. See note 139 supra. 
attorney fee doctrines should sometimes be applied to PUC proceedings. It suggests that the preferable method for determining when an award is appropriate is to determine whether a court would award fees in similar circumstances, but cautions against expanding the equitable doctrines to reach cases where a court would not award fees. It remains to be determined, however, if the PUC could, if it chose to do so, estabhish a general fee reimbursement program to compensate public participants who do not qualify for an award under any of the equitable doctrines, im order to ensure adequate participation im PUC liearings.

\section{$\mathrm{V}$}

\section{The PUC's Power to Institute a Public} Participation Reimbursement Program

In addition to deciding that the PUC had no authority to award attorney fees to ratemaking participants under the judicial theories, the court also held that the PUC was not required by statute to imclude public participation costs $\mathrm{m}$ the expenses charged to ratepayers. While this holding was legally sufficient to decide the case, the court in the same sentence suggested that the statutes imight not even permit the PUC to shift such costs to ratepayers absent further legislative action. ${ }^{153}$ This Note argues that the court should not follow this dictum in future cases but should defer to any future PUC decision to adopt a public reimburseinent program. ${ }^{154}$

The court objected to permitting the PUC to adopt a fees reimburseinent program because the legislature had not expressly delegated such authority to the PUC. ${ }^{155}$ This argument contradicts the court's

153. 25 Cal. 3d at 911, 603 P.2d at 53, 160 Cal. Rptr. at 136 ("we are not persuaded that sections 701 and 728 require, or even permit, the commission to shift TURN's 'public participation costs' to the ratepayers").

154. By pointing out that the PUC has construed its enabling statutes as not permitting such a program, $25 \mathrm{Cal}$. 3d at 912, $603 \mathrm{P} .2 \mathrm{~d}$ at 53-54, $150 \mathrm{Cal}$. Rptr. at 136, the court left the door open for future deference to a PUC decision to institute such a program. In Greene County Planning Bd. v. Federal Power Comm'n, 559 F.2d 1227 (2d Cir. 1977) (en banc), cert. denied, 437 U.S. 1086 (1978), an analogous federal case, the Court of Appeals for the Second Circuit upheld an agency decision that it lacked statutory authority to award attorney fees. Like CLAM, Greene contains broad language saying that only the legislature could institute such a program. Nevertheless, later courts have limited Greene to situations where the agency declines to award fees. See notes 49-52 and accompanying text supra.

Additional evidence that the court might defer to a future PUC decision to institute a fee reimbursement program is supplied by the court's approving reference to the federal Public Regulatory Policies Act of 1978 (PURPA), 16 U.S.C. $\$ \S 2601-2645$ (Supp. III 1979). 25 Cal. 3d at 912 n.9, 603 P.2d at 53 n.9, 160 Cal. Rptr. at 136 n.9. Under PURPA, if an electric utility consumer has "substantially contributed" to the state's partial or complete adoption of certain ratemaking standards and has undergone financial hardship in domg so, the consumer may collect legal fees from the utility unless the state regulatory agency (the PUC in California) adopts an alternative fee reimbursement program. 16 U.S.C. $\$ 2632$ (Supp. III 1979).

155. 25 Cal. 3d at 911-12, 603 P.2d at 53, 160 Cal. Rptr. at 136. 
earlier recognition that section 701 of the Public Utilities Code permits the PUC to do all things "which are necessary and convenient" to regulating public utilities. ${ }^{156}$ Of course, the legislature could investigate the problem and imstitute a conprehensive reimbursement scheme. But if the PUC determines that a reimbursement program for ratemaking participants is necessary to aid it in its statutory duty to "determine and fix . . . just, reasonable, or sufficient rates," 157 this standard of necessity and convenience would seem to be satisfied.

Moreover, Professor Davis advocates that a court should defer to an agency's interpretation of its own organic statutes when, as here, those statutes give the agency broad discretion and the agency has greater administrative expertise on the issue than the court. ${ }^{158}$ This principle would suggest that the PUC and not the court is in the best position to decide whether it is wise to create a reimbursement program. Reimbursement plans present questions of whether the payment of participants' fees will assist the PUC in making decisions in the public imterest and, if so, how such a program is to be structured. Both of these issues are outside the court's area of expertise. The court cannot predict the ramifications of a payment scheme on participation before the PUC or on the PUC's administrative machinery. The PUC's experience with public participation and its knowledge of its own administrative process place it $\mathrm{m}$ a better position to assess the issues involved. This approach also finds support in the federal case law. Federal courts have allowed federal agencies to imterpret their broad organic statutes so as to permit public participation reimbursement programs. ${ }^{159}$

The CLAM court was also concerned that a fee reimbursement plan would create an "administrative quagmire." 160 The court was justifiably concerned that it could not adequately assess the administrative and policy ramifications of a fee reimbursement program, and its decision to put the burden on the legislature is understandable. The PUC, however, is in as good a position to assess the issues as the legislature.

156. Id. at 905,603 P.2d at 49,160 Cal. Rptr. at 132 (quoting CAL. PuB. Util. Code $\S 701$ (West 1975)).

157. Cal. Pub. Util. Code $\$ 728$ (West 1975).

158. $4 \mathrm{~K}$. Davis, Administrative Law Treatise $\S 30.09$ (1958).

Professor Davis' principle also explains why the court was qualified to contradict the PUC's judgment in deciding whether the PUC could grant the equitable fee awards. While the court has bittle expertise in administrative public participation scheines, it has great expertise in the application of the judicially created equitable fee award doctrines. Over the past few decades, the court has gradually established the doctrinal requirements of the fee awards, applying thein in compelling but narrowly defined situations. This long history of developinent and application qualifies the court to judge the feasibility of PUC use of the fee awards.

159. See note 154 supra, and text accompanying notes $73-77$ supra.

160. $25 \mathrm{Cal} .3 \mathrm{~d}$ at $911,603 \mathrm{P} .2 \mathrm{~d}$ at 53, $160 \mathrm{Cal}$. Rptr. at 136. 
The legislature created the PUC and gave it expansive powers because it did not have the time or expertise to deal with the details of regulating utilities. ${ }^{161}$ The PUC has many years of experience with public participation and intimate knowledge of its own administrative processes. The PUC can assess the need for a fee prograin and evaluate the effect it would have on PUC proceedings. ${ }^{162}$

A possible argument in favor of requiring the legislature to formulate a reimburseinent prograin instead of leaving the inatter to the PUC is that the legislature is inore politically responsive than the PUC. ${ }^{163}$ However, the PUC is not necessarily unresponsive. First, if the PUC funded reimburseinents out of its own budget, the legislature would implicitly approve the plan each time it funded the PUC. ${ }^{164}$ Next, even if the PUC funded reimbursements by raising rates, ${ }^{165}$ there would be checks on the PUC's overimdulgence. If the legislature disapproved of the PUC's actions, it could adopt legislation limiting the PUC's authority. ${ }^{166}$ Even short of legislative action, the consumers would probably have input during PUC hearings into any decision to initiate a participation program. ${ }^{167}$ There is little risk that the arguments against a proposed program would be inadequately aired, as the utilities, the obvious opponents of such a program, have both the resources and expertise to mount a strong opposition campaign.

A PUC-developed reimbursement plan would serve important public policies. In a recent decision, the PUC conceded that "broad public participation is essential for the inamtenance of the integrity of our processes." 168 Ratepayers must already bear the cost of the PUC staff and the utilities' attorney fees. ${ }^{169}$ It seeins "a small price to ask the

161. See generally I. Sharfman, The Interstate Commerce Commission: A Study nN Administrative LAw and Procedure PART Two 349 (1931) ("The . . . expansion of legislative activity has given rise to the problem of devising effective machinery of enforcement: the difficulty of dealing . . . with the large mass of proceedings inevitably involved under many of the new laws has . . . stimulated the establishunent of special tribunals charged with the administration of specific legislative enactments.").

162. The PUC has already considered such matters in fashioning regulations governing reimbursement of participants in electric utility ratemaking under PURPA. Cal. PUC Decision No. 91909 (June 17, 1980); 20 CAL. ADMIN. CODE $\$ \S 76.03-76.05$ (Aug. 16, 1980).

163. The five PUC commissioners are appoimted by the governor, with the senate's approval, for staggered six-year terms. CAL. CoNST. art. 12, $\$ 22$.

164. The PUC is funded in the state budget. See note 17 supra.

165. The PUC did so in adopting PURPA, Cal. PUC Decision No. 91909, slip op. at 11 (June 17,1980 ), by treating reinburseinents as operating expenses.

166. The legislature has in the past enacted special legislation to direct the PUC when it thought a particularly important public policy was at stake. See, e.g., CAL. PUB. UTIL. Code $\S 739$ (West 1975 \& Supp. 1981) (establishing "lifeline" rates for residential ratepayers).

167. See, e.g., Cal. PUC Decision No. 91909 (June 17, 1980) (summarizing positions of various participants im PUC proceedings investigating need for PURPA).

168. Id. at 6.

169. Id. 
ratepayers to pay to ensure" that the PUC also hears and considers as many public views as possible. ${ }^{170}$ Thus, although the decision in $C L A M$ to allow the PUC to award attorney fees to participants in at least some administrative proceedings advances the goal of public participation, the decision ought to be expanded to cover otlrer instances appropriate for equitable fee discretion, and it ought not to foreclose any efforts by the PUC to institutionalize a broader attorney fee program.

\section{CONCLUSION}

In CLAM v. PUC, the California Supreme Court decided, contrary to the agency's conclusion, that the PUC had the power to inake a common fund attorney fee award in a reparations proceeding, because the proceeding was "quasi-judicial." But the court held that the PUC could not grant fees in a ratemaking proceeding, as ratemaking is a "quasi-legislative" function. This Note argues that the court's reasonmg is broad enough to permit the PUC to give awards under the substantial benefit and private attorney general theories as well as the common fund doctrine. This Note criticizes the court's "quasi-judicial" and "quasi-legislative" models, however, arguing that neither the type of procedures followed nor the label attached to the proceedings provides an adequate basis for deciding when an attorney fee award is appropriate. The proposal advanced in this Note is for the PUC to decide when equitable attorney fee awards are appropriate by examining whether the criteria and policies of the equitable attorney fee doctrines are met.

The CLAM court also agreed with the PUC that the Commission had insufficient statutory authority to implement a program under its rulemaking powers to award attorney fees to public participants. The court suggested that only the legislature could initiate suclr a program. This Note concludes that even without legislative action, the PUC has sufficient power under its broad organic statutes to implement a comprehensive prograni to compensate participants in its proceedings, should it choose to do so.

Linda M. Ross*

170. Id.

* A.B. 1979, University of California, Berkeley; third-year student, Boalt Hall School of Law, University of California, Berkeley. 